\title{
The Effect of Auditor Judgment and Professional Skepticism on Internal Audit Quality
}

\author{
Egi Rahmansyah ${ }^{1}$, Abdul Pattawe ${ }^{1 *}$, Lucyani Meldawati ${ }^{1}$, M. Ikbal Abdullah ${ }^{1}$, \\ Masruddin $^{1}$, Muhammad Din ${ }^{1}$ \\ ${ }^{I}$ Department of Accounting, Faculty of Economics and Business, Tadulako University, Palu, Indonesia \\ *Corresponding author. Email: abdullpattawe@gmail.com
}

\begin{abstract}
This study aims to examine and analyze the effect of auditor judgment and professional skepticism on the quality of internal audit at the Inspectorates of Central Sulawesi Province and Palu City. This type of research is survey research. Data was collected by distributing questionnaires to 54 auditors working in the Inspectorate of Central Sulawesi Province and Palu City. The analytical tool used is multiple linear regression analysis with the help of SPSS version 16.0 program. The results showed that the auditor's judgment had a positive and significant effect on the quality of internal audit, while professional skepticism had a positive and significant effect on the quality of internal audit. Auditor judgment and professional skepticism simultaneously affect the quality of internal audit.
\end{abstract}

Keywords: Audit, Quality, Judgment, Skepticism.

\section{INTRODUCTION}

In the current era of Indonesian government, legal problems are increasingly rampant in Indonesia such as corruption, collusion, nepotism, and the use of state money for personal gain. A survey conducted by Transparency International in 2018 on its official website stated that Indonesia was ranked 89th out of 180 countries with a score of 38 out of the highest score of 100. The corruption perception index in 2019 got a rating of 85 [1];[2]. This shows that Indonesia is a country with high corruption.

In order to realize good governance and clean governance, it is necessary to implement a reliable internal control and inspection function. A good internal control system in accountability for the use of funds for the administration of government ensures the implementation of activities in an equitable manner, distributed throughout the public sector and in accordance with established policies and plans as well as applicable regulations economically, efficiently, and effectively.

There are three aspects that support the realization of good governance: 1) namely supervision, as an activity that oversees government performance, 2) internal control, as an activity of the executive to ensure that policies and management systems are implemented. properly, so that organizational goals can be achieved. effective, and 3) examination, referring to the activities carried out by the government on the results of government performance related to the standards that have been set [3]; [4]; [5].

The internal control function in the government's internal audit is carried out by the Government Internal Control Apparatus (APIP), namely the Inspectorate. In accordance with the provisions of Government Regulation Number 41 of 2007 concerning Regional Apparatus Organizations, the Inspectorate is the element that oversees the implementation of regional government. The Regional Inspectorate has the task of supervising the implementation of government affairs in the regions/provinces, the implementation of fostering the implementation of regental/municipal government affairs, and the implementation of government affairs in the districts/cities. The roles and functions of the Provincial, Regency/City Inspectorates are generally regulated in Article 4 of the Regulation of the Minister of Home Affairs Number 64 of 2007. It is stated that in carrying out the task of supervising government affairs, the Provincial, 
Regency/City Governments have the functions of planning supervision programs, formulating policies and facilitating supervision, examination (audit), investigation, testing, and assessment of the internal control tasks carried out.

The results of a quality internal audit indicate good and responsible supervision and management of government finances. If the quality of internal audit is low, then it provides leeway for government agencies to make mistakes and irregularities in the use of the budget which results in the risk of lawsuits against government officials who implement them.

News released by Sulteng BPK in May 2020 BPK submitted the 2020 Examination Results Report to regional heads of Central Sulawesi Province and Palu City as well as DPRD leaders, and obtained an Unqualified Opinion on Regional Government Financial Statements, for 7 seven consecutive years. This positive result certainly cannot be separated from the role of the Inspectorate as Supervision and Audit. However, according to BPK, there are still problems that need attention in the internal control system and compliance with laws and regulations. BPK also asked the regional head of Central Sulawesi to pay close attention and seriously implement BPK's findings and recommendations on LKPD findings.

Based on the descriptions and problems that the researchers describe, the researchers are interested in researching the effect of auditor considerations and professional skepticism on the quality of internal audit at the regional inspectorate of Central Sulawesi Province and Palu City.

\section{THEORETICAL REVIEW AND HYPOTHESIS DEVELOPMENT}

\subsection{Internal Audit Quality}

Internal audit quality is the attitude of the auditors in carrying out their duties which is reflected in the results of their reliable examinations in accordance with applicable standards. Elfarini [6] stated that the measurement of the quality of the audit process is centered on the performance of the auditor and compliance with the standards that have been outlined. The Government Accountability Office defines audit quality as adherence to professional standards and contractual ties during auditing. Audit standards serve as guidance and a measure of the quality of the auditor's performance [7].

There are four things that are considered to have a relationship with audit quality, namely: 1) the length of time the auditor has conducted an examination of an agency or tenure: the longer an auditor has audited the same client, the audit quality will be lower, 2) the number of clients: the more the number of clients, the better the audit quality will be because auditors with a large number of clients will try to maintain their reputation, 3) the financial health of the client: the healthier the client's financial condition, the more likely the client will be a pressure the auditor not to follow the standard, and 4) review by a third party: audit quality will increase if the auditor knows that the results of his work will be reviewed by a third party [8].

Government Internal Supervisory Apparatus Audit Standards Regulation of the state minister for State Apparatus Empowerment Number: PER/05/M.PAN/03/2008 concerning Audit Standards for Government Internal Supervisory Apparatuses, consisting of:

1. General Standard

a. APIP's vision, mission, objectives, authorities, and responsibilities must be stated in writing, approved and signed by the highest leadership of the organization.

b. In all matters relating to the audit, APIP must be independent and its auditors must be objective in carrying out their duties.

c. Auditors must have the knowledge, skills and other competencies needed to carry out their responsibilities.

d. The auditor must use his professional expertise carefully and carefully and must be careful in every assignment.

2. Performance Audit Implementation Standards

a. In each performance audit assignment, the auditor must develop an audit plan.

b. At each stage of the performance audit, the auditor's work must be supervised to ensure that the objectives can be achieved, quality is guaranteed, and is able to improve the auditor's expertise.

c. Auditors must gather evidence to support performance audit conclusions and findings

d. Auditors should develop findings found during performance audit work

e. Audit documents must be stored properly and systematically to facilitate review, reference, and analysis.

\section{Performance Audit Reporting Standards}

a. The auditor must immediately make a report on the results of the audit in accordance with the format of the assignment. 
b. The auditor in making the report on the audit results must be in writing and immediately to avoid the possibility of misinterpretation or conclusions.

c. The report made by the auditor must be communicative, so that it can be understood by the auditee or other related parties.

d. The audit report must be timely, complete, accurate, objective, convincing, clear, and as concise as possible.

e. The auditor must ask the auditee for feedback on conclusions, findings, recommendations and corrective actions.

f. The audit result report is submitted to the head of the organization being audited and other authorized parties in accordance with the laws and regulations.

4. Performance Audit Follow-up Standards

a. The auditor must continue to communicate with the auditee to complete and follow up on the findings and recommendations given

b. Auditors must monitor follow-up on findings and recommendations

c. The auditor must report the status of findings and recommendations that have not been followed up.

d. Auditors must cooperate with law enforcement officers in following up on acts of non-compliance with laws and regulations

\subsection{The Effect of Auditor's Judgment on the Quality of Internal Audit}

Audit judgment is the auditor's policy in determining an opinion regarding the audit results which refers to the formation of an idea, opinion or estimate about an object, event, status or other type of event [9].

Judgment in auditing is certainly very necessary because the audit is not carried out on all evidence. The auditor must have the ability to consider evidence and information that is felt to support the conduct of the audit. The evidence is then used to provide conclusions and recommendations to the auditee in accordance with the audit objectives [10].

Judgment is influenced by audit assessment. This needs to be done because basically the audit is carried out based on a sample, in which not all data must be questioned and researched [11]. The ability to assess and conclude must also be appropriate. The judgment auditor is the one who determines the level of materiality in a financial report. Professional judgment is at the implementation stage in the form of findings in the field, audit risk, and audit evidence in which the auditor assesses according to the facts in the field. Professional judgment at the reporting stage considers making a manuscript of audit results which will be reexposed and discussed so that the auditor can provide audit recommendations that good and trustworthy [12].

Based on the description above, the following hypothesis can be formulated that:

H1: Judgment auditor affects the quality of internal audit.

\subsection{Effect of Professional Skepticism on Internal Audit Quality}

According to [13], professional skepticism is a behavioral attitude that is full of questions in mind, being alert to situations that indicate possible misstatements due to error or fraud and an assessment of the evidence. These risks can be occurred in various decisions such as selecting appropriate audit methods and techniques.

The more additional information the auditor obtains with skepticism, the more accurate the evidence will be to prove whether or not the symptoms of fraud are true. Internal audit quality requires the auditor to collect sufficient and relevant evidence. Therefore, an auditor must think critically in collecting and understanding audit evidence. Low auditor skepticism will cause the auditor to not be able to produce a good quality internal audit. It is because the auditor will easily believe the evidence and information obtained without any evidence and other supporting information. If the attitude of professional skepticism possessed by the auditor is high, the better the audit quality produced by the auditor will be [14]; [15].

Based on the description above, the hypothesis can be formulated as follows:

H2: Professional skepticism affects the quality of internal audit.

\subsection{The Effect of Auditor Judgment and Professional Skepticism on Internal Audit Quality}

Professional judgment and skepticism is an important attitude that must be possessed by the auditor in determining the quality of the audit. Judgment in auditing is necessary because not all evidence is questioned, researched and evaluated. According to [16], judgment is influenced by audit assessment, because basically the audit is carried out based on samples and, and not all evidence is audited. Therefore, proper judgment is needed to produce good audit quality. Not only that, judgment auditor is 
necessary to determine the level of materiality of a financial report. Proper judgment is needed in the audit. The judgment auditor also determines the audit plan and the sample to be audited. This is continuous with professional skepticism. Professional skepticism refers to an attitude that always questions and evaluates audit evidence critically. Audit evidence collected by auditors who have a high skepticism will prove it with a very relevant and accurate explanation of the evidence being tracked, and do not just believe in the auditee's statements to look for supporting evidence.

Based on the description, the two variables of auditor judgment and professional skepticism are interested in simultaneously researching because judgment auditors determine the level of materiality of financial statements. This is supported by auditor skepticism because before considering the level of materiality of a financial report, professional skepticism is certainly needed to find out, analyze, evaluate and look for supporting evidence before stating that the financial statements are misstated or the amount of value omitted.

So, based on the description of the theory, the following hypotheses can be formulated:

H3: There is an effect of auditor's judgment and professional skepticism on internal audit quality.

\section{RESEARCH METHODS}

This research was conducted by sending questionnaires to 54 auditors at the Inspectorate Office of Central Sulawesi Province and Palu City. The data was processed using multiple linear regression with the help of SPSS.

\section{RESULT}

\subsection{Multiple Linear Regression Analysis Results}

The output of the SPSS for windows version 16.0 program shows the results of multiple regression in Table 1. Based on the regression coefficient values obtained from the results of the multiple linear regression analysis, then it is entered into the multiple regression equation model with the following formula:

$\mathrm{Y}=23,598+0,476 \mathrm{X} 1+0,456 \mathrm{X} 2+\mathrm{e}$

The first hypothesis testing showed that based on the results of the F-test, it illustrates that the first hypothesis in this study which states that auditor judgment and professional skepticism on the quality of internal audit have a simultaneous effect can be accepted. So, it can be seen that the independent variable in this study is a factor that can affect the quality of internal audit and is an important variable that must be considered to support the achievement of a quality audit. Judgment in auditing is certainly very necessary because judgment is required for an audit not to be carried out on all evidence. The auditor must have the ability to consider evidence and information that is deemed to be able to support the implementation of the audit. The evidence is then used to provide conclusions and recommendations to the auditee in accordance with the audit objectives. Judgment is influenced by audit assessment. This needs to be done because basically the audit is carried out based on a sample, in which not all data must be questioned and researched. The ability to assess and conclude must also be appropriate. The judgment auditor is the one who determines the level of materiality in a financial report.

This is supported by auditor skepticism because before considering the level of materiality of a financial report, professional skepticism is certainly needed to find out, analyze, evaluate and seek supporting evidence before stating that the financial statements are misstated or the amount of value omitted. Skepticism is also very important for audit quality according to the facts found in the field. The more findings obtained, the more quality the audits carried out. To look for findings, especially negative findings, a critical attitude is needed in other words, professional auditor skepticism. Things like this also strongly support the creation of the effectiveness of the audit quality. But, according to the auditors that the more negative findings, the lower the auditor's performance will be in the process of fostering regional organizations.

According to the auditor, the reporting of findings in the field is stated in the audit work paper. All findings must also be stated in the working paper, and the output of the findings will become audit recommendations. Recommendations will still get a follow-up or review from the auditor whether the recommendations have been implemented or not, because the audit working paper will also be reviewed by an external audit, namely the BPK. If there are findings that can be said to be material and have not been resolved within the period, it will affect the opinion of the external auditor or BPK. 
Table 1. Results of Multiple Linear Regression Analysis

\begin{tabular}{|l|l|l|l|l|}
\hline $\begin{array}{l}\text { Independent } \\
\text { Variable }\end{array}$ & $\begin{array}{l}\text { Regression } \\
\text { Coefficient }\end{array}$ & $\begin{array}{l}\mathrm{t}- \\
\text { count }\end{array}$ & Sig. & $\begin{array}{l}\mathrm{r}- \\
\text { partial }\end{array}$ \\
\hline $\mathrm{X} 1$ & 0,476 & 1,722 & 0,091 & 0,234 \\
\hline $\mathrm{X} 2$ & 0,456 & 2,751 & 0,008 & 0,359 \\
\hline Constanta $=23,598$ \\
\hline Multiple- $\mathrm{R}=0,454$ \\
\hline $\mathrm{F}$ count $=6,622$ \\
\hline Sig. $\mathrm{F}=0,003$ \\
\hline $\mathrm{R}$. Square $=0,206$ \\
\hline Adjusted $\mathrm{R}$ Square $=0,175$ \\
\hline$\alpha=0,10$ \\
\hline
\end{tabular}

The facts found in the field stated that an understanding of the internal control system will also affect the effectiveness of audit quality. An understanding of SPI is an important factor in planning audits for auditees as well as guided by the principle as an attitude that must be carried out by the auditor. Doing it in accordance with general audit standards is also a construction of internal audit quality indicators.

The second hypothesis testing showed based on the results of the t-test obtained, the significant effect indicated by the significance level is smaller than the $10 \%$ confidence level, namely $0.008<0.10$ indicating that professional skepticism has an important role in the quality of internal audit. The mean value is 4.60 on the basis of very good or very high-quality interpretation. It indicates that professional skepticism has a positive and significant effect on the quality of internal audit.

The dimension of professional skepticism also illustrates that the higher the professional skepticism, the better the quality of internal audit. In accordance with the research conducted on auditors and looking at the results of the tabulation of respondent's answer data, it can be seen that in carrying out the examination, the auditor has collected audit evidence based on skepticism and prudence in making decisions. Skepticism also supports in obtaining existing findings, especially negative findings. According to the auditors of the regional inspectorate of Central Sulawesi, the level of skepticism of the auditors varies, depending on which audit should be carried out, such as an investigative audit. This requires a strong attitude of skepticism for the audit planning process, audit implementation in the field and audit follow-up, as in the findings of the departmental OPD. This is also different from the process of coaching auditors to OPD which does not require skepticism, because usually in terms of coaching only carry out education and training for auditors.
The results of the study show that professional skepticism has a positive influence on the quality of internal audit. It means that auditors who work at the Inspectorate of Central Sulawesi Province and Palu City have a fairly good level of professional skepticism in conducting examinations.

Third hypothesis testing showed that based on the results of the t-test obtained, the significant effect indicated by the significance level is smaller than the $10 \%$ confidence level, namely $0.091<0.10$. It indicates that the auditor's judgment according to the basis of interpretation is said to be of good quality with a mean value of 4.15 .

It can be seen that the auditor's judgment has a positive and significant effect on the quality of internal audit. The sign of a positive regression coefficient illustrates that the better the auditor's judgment it will help the auditor in critically assessing the risks faced. They will also take into account these risks in various decisions such as choosing the right audit methods and techniques, assessing the audit evidence collected. They have a better ability to produce audit quality to produce recommendations for auditee improvement. Based on the facts found in the field that according to the Palu City regional inspectorate auditor's judgment auditor, the internal auditor's way of working is also more directed to the process for 1 period of work for OPD. This is different from external auditors such as BPK who receive results and examine LKPD and OPD performance in Central Sulawesi and Palu City.

The dimension of judgment or consideration of the auditor in auditing is an attitude of necessity in auditing. According to the auditors of the Central Sulawesi regional inspectorate that the level of judgment of auditors varies, usually more dominant in the length or the experience as an auditor so that it affects the level of knowledge and skills at the time of auditing. Therefore, new auditors will not necessarily go directly to auditing. In the beginning, they need guidance and training from senior auditors in the local area.

\section{CONCLUSION}

The findings of this study indicate that the auditor's judgment has a positive and significant effect on the quality of internal audit. Professional skepticism has a positive and significant effect on the quality of internal audit. Auditor judgment and professional skepticism have a positive and significant effect on audit quality at the regional inspectorate of Central Sulawesi province and Palu city.

It is expected that the auditors of the inspectorate of the Province of Central Sulawesi and Palu City to uphold professionalism and independence. From the 
findings in the field, auditors make judgments sometimes tend to use their hearts in auditing so that it will affect the professionalism and independence of an auditor. It is expected to increase human resources in the field of accounting because from the data obtained, auditor with accounting education are still few. It is feared that this will affect the quality of the audit, especially in the audit of financial statements.

\section{AUTHORS' CONTRIBUTIONS}

First Author: writing, data analysis and field research; Second and third authors: method, data analysis; Fourth, fifth and sixth authors: validation.

\section{ACKNOWLEDGMENTS}

Thanks to Tadulako University for providing research and financial support, and to the conference committee for providing the opportunity to present this article.

\section{REFERENCES}

[1] Transparency International, "CORRUPTION PERCEPTIONS INDEX 2018,” 2018. https://www.transparency.org/en/cpi/2018/ind ex/dnk.

[2] Transparency International, "CORRUPTION PERCEPTIONS INDEX 2019,” 2019. https://www.transparency.org/en/cpi/2019/ind ex/nzl.

[3] N. N. Afiah and P. C. Azwari, "The effect of the implementation of government internal control system (GICS) on the quality of financial reporting of the local government and its impact on the principles of good governance: A research in district, city, and provincial government in Sou," ProcediaSocial Behav. Sci., vol. 211, 2015, pp. 811818.

[4] M. Srivastava, "Good Governance - Concept, Meaning and Features: A Detailed Study (December 26, 2009)," 2009. https://ssrn.com/abstract=1528449

or http://dx.doi.org/10.2139/ssrn.1528449.

[5] R. P. Sari, S. Hastuti, and O. Tannar, "Audit Quality Based on Internal Audit Capability Model (IACM) and Gender as Mediating Variabel in the Public Sector," J. Econ. Business, Gov. Challenges, vol. 2, no. 1, 2019, pp. 22-38.

[6] E. C. Elfarini, "Pengaruh Kompetensi dan
Independensi Auditor Terhadap Kualitas Audit (Studi Empiris Pada Kantor Akuntan Publik di Jawa Tengah)," Universitas Negeri Semarang, 2007.

[7] D. F. Prawitt, J. L. Smith, and D. A. Wood, "Internal audit quality and earnings management," Account. Rev., vol. 84, no. 4, 2009, pp. 1255-1280.

[8] M. N. Alim, T. Hapsari, and L. Purwanti, "Pengaruh Kompetensi dan Independensi terhadap Kualitas Audit dengan Etika Auditor sebagai Variabel Moderasi,” 2007.

[9] Mulyadi, Auditing Buku 1, 6th ed. Jakarta: Salemba Empat, 2002.

[10] American Institute of Certified Public Accountants. Auditing Standards Executive Committee (AICPA), The Effect of an Internal Audit Function on the Scope of the Independent Auditor's Examination. AICPA. 1976.

[11] P. R. Brown, "Independent auditor judgment in the evaluation of internal audit functions," $J$. Account. Res., 1983, pp. 444-455.

[12] A. Schneider, "The reliance of external auditors on the internal audit function," $J$. Account. Res., 1985, pp. 911-919.

[13] T. M. Tuanakotta, Berpikir kritis dalam Auditing. Jakarta: Salemba Empat, 2013.

[14] N. McCoy, R. D. Burnett, M. E. Friedman, and M. Morris, "Internal audit: How to develop professional skepticism," J. Corp. Account. Financ., vol. 22, no. 4, 2011, pp. 3-14.

[15] M. W. Nelson, "A model and literature review of professional skepticism in auditing," Auditing, vol. 28, no. 2, 2009, p. 1.

[16] S. E. Bonner and B. L. Lewis, "Determinants of auditor expertise," J. Account. Res., vol. 28, 1990, pp. 1-20. 